\title{
Bacteriocinogeny and Lysogeny in the Genus Pseudomonas
}

\author{
By ANN C. PATERSON \\ Department of Microbiology, University of Sheffield*
}

(Received 24, July 1964)

\begin{abstract}
SUMMARY
Bacteriocinogeny and lysogeny have been investigated in strains of $\boldsymbol{P}$ seudomonas aeruginosa, $\boldsymbol{P}$. fluorescens and $\boldsymbol{P}$. ovalis. The 39 strains of $\boldsymbol{P}$. aeruginosa were all bacteriocinogenic and 32 were also lysogenic. No bacteriocine production was detected in 8 strains of $\boldsymbol{P}$. fluorescens, although 3 were lysogenic. The one strain of $\boldsymbol{P}$. ovalis studied was neither bacteriocinogenic nor lysogenic for $\boldsymbol{P}$. aeruginosa or $\boldsymbol{P}$. fuorescens. Typing of the bacteriocines of $\boldsymbol{P}$. aeruginosa on the basis of their action spectra showed that 25 fall into four main groups; the bacteriocines of 6 strains could not be fitted into any definite group.
\end{abstract}

\section{INTRODUCTION}

Bacteriocine production by a strain of $P$ seudomonas aeruginosa $(\boldsymbol{P} \cdot$ pyocyanea $)$ was described by Jacob (1954), and investigations into the bacteriocines of 21 Pseudomonas species have since been made by Hamon and co-workers (Hamon, 1956; Hamon, Véron \& Péron, 1961). Bacteriocines produced by $\boldsymbol{P}$. fluorescens are known as fluocines; those of $\boldsymbol{P}$. aeruginosa are known as pyocines. The present paper reports on a survey of bacteriocine production and sensitivity among strains belonging to 3 Pseudomonas species. In addition, the activity spectrum of the pyocine produced by each of 31 strains of $P$. aeruginosa has been determined against the other 30 strains in an attempt to establish a rational basis for the classification of the pyocines.

Bacteriocinogeny and lysogeny are both very widespread in the genus Pseudomonas, the majority of the strains of $\boldsymbol{P}$. aeruginosa studied by Hamon being either pyocinogenic or lysogenic or both. He also found that, while some of the pyocines were active against several strains of $\boldsymbol{P}$. fluorescens in addition to strains of $\boldsymbol{P}$. aeruginosa, the fluocines produced by strains of $P$. fluorescens were active only against other strains of $\boldsymbol{P}$. fluorescens. Bacteriocine production was rare among the other 19 species examined. The 30 bacteriocines studied in detail were each found to show a different action spectrum towards sensitive strains. The specific resistance or sensitivity of bacterial strains to bacteriocines produced by their own or another species has been noted with many types of bacteriocine (Frédéricq, 1948; Nagy, Alföldi \& Ivánovics, 1959; Brubaker \& Surgalla, 1961; Hamon \& Péron, 1961, 1963) and has been used by Frédéricq $(1948,1953)$ as the basis for the classification of colicines.

The production of some bacteriocines, like that of certain lysogenic bacteriophages, is inducible by ultraviolet (u.v.) radiation. In some cases (Jacob, 1954; Ivánovics \& Alföldi, 1954) lysis of u.v.-irradiated cultures occurs after a characteristic latent

* Present address : Department of Biological Chemistry, Marischal College, Aberdeen.

Vol. 39, No. 2, was issued 28 June 1965 
period, with the release of large quantities of bacteriocine. Lysis is not, however, an obligatory accompaniment of induced bacteriocine production (Ben-Gurion \& Hertman, 1958; Hamon \& Péron, 1963). The present investigation includes a study of the effect of u.v. irradiation upon bacteriocine production by $P$.aeruginosa strains.

\section{METHODS}

Organisms. Pseudomonas fluorescens strains A, Ns, KB 1, co 1, CO 2, s1-A, s 1-B and s 2 , and $\boldsymbol{P}$. ovalis Chester were from the culture collection of this laboratory. $P$. aeruginosa strains C4, c6 and c10 were kindly supplied by Dr L. Dickinson; strains 20, 21, 24/1, 24/2, 73, 117, 118, 119, 130 and 149 by Dr M. Rhodes; strains $1,2,3$ and 29 (as amino acid-requiring mutants) by Dr B. W. Holloway; strains $1999,2000,5083,5940,6749,6750,6751,7244,7771,8058,8060,8203,8505$ and 8506 were obtained from the National Collection of Type Cultures. In addition, nine cultures, nominally $P$. aeruginosa, numbered 160, 162, 207, 244, 260, 306, 331, 332 and 333 were isolated in the Department of Bacteriology of this University.

Media. Nutrient broth contained (g./l.) Oxoid tryptone 20, Oxoid Lab Lemco $2: \mathrm{pH} 7$. Broth cultures of Pseudomonas aeruginosa were shaken at $37^{\circ}$, those of $\boldsymbol{P}$. fluorescens and $\boldsymbol{P}$. ovalis at $30^{\circ}$. Peptone agar plates contained $c .30 \mathrm{ml}$. medium comprising (g./l.) Oxoid peptone 10, Oxoid Lab Lemco 1, $\mathrm{NaCl}$ 10, New Zealand agar(Northern Media Supply, Ltd., Leeds) 10 : pH7. Soft agar for overlayering contained only $0 \cdot 6 \%(\mathrm{w} / \mathrm{v})$ agar.

Measurement of turbidity of cultures. Irradiated cultures were incubated in conical flasks fitted with side arms into which the cultures could be tipped, enabling turbidity measurements to be made in an EEL nephelometer without sampling.

Irradiation of cultures. Samples $(10 \mathrm{ml}$.) of tryptone broth cultures growing in exponential phase (about $5 \times 10^{8}$ bacteria $/ \mathrm{ml}$.) were rocked by hand for $30 \mathrm{sec}$. in an open $9 \mathrm{~cm}$. Petri dish $1 \mathrm{~m}$. below a Hanovia Chromatolite low-pressure mercury vapour lamp (no filter). After 2-hr incubation, organisms and debris were removed by centrifugation and the supernatant fluids sterilized by heating to $55^{\circ}$ for $30 \mathrm{~min}$.

Detection of bacteriocine and phage. The presence of a bacteriocine can be detected by the inhibition of growth of a sensitive indicator organism. Growth inhibition on a seeded indicator plate shows as characteristic clear zones in the area of the applied bacteriocine, and may be indistinguishable from confluent lysis caused by phage. The bacteriocine activity, unlike bacteriophage, cannot be transferred from the inhibition zone to a second indicator plate (Gratia, 1925). The tests used in the present investigation were designed to distinguish activity due to bacteriocine from that due to phage, since many strains produced both bacteriocine and lysogenic phage, and the indicator organism might be sensitive to both agents.

Qualitative tests for the presence of a bacteriocine make use of bacteriocine production on the plate during growth of the producer organism, the producer bacteria being killed before seeding with the indicator. A quantitative estimate of bacteriocine concentration may be obtained by applying to the surface of a seeded indicator plate standard drops of serial dilutions of a cell-free solution of the bacteriocine. The intensity of inhibition of the indicator growth decreases as the bacteriocine concentration decreases, and an end-point can be taken as the highest dilution at 
which a zone of inhibition is discernible. This technique also helps to distinguish between inhibition due to bacteriocine and that due to phage, since at high dilutions phage produces discrete plaques on the indicator lawn.

All Pseudomonas strains, except strains 1, 2, 3 and 29 of Pseudomonas aeruginosa, were first screened rapidly for bacteriocine and phage production by placing drops of the cell-free supernatant fluid of an overnight culture (undiluted) on seeded indicator plates. The presence of phage was checked by transferring material from each inhibition zone with a platinum wire into $1 \mathrm{ml}$. tryptone broth, and replating a drop on a second indicator plate. In this way, a qualitative survey of the extent of bacteriocinogeny and lysogeny among the strains was made. Thirty-one strains, selected because they had been characterized by other workers as authentic Pseudomonas aeruginosa strains, were exhaustively tested by assaying serial dilutions of the supernatant fluids of u.v.-irradiated cultures. Examination of the inhibition zones revealed the presence of pyocine and/or phage, and gave a quantitative measure of the sensitivity of each indicator to each pyocine. These $\boldsymbol{P}$. aeruginos $a$ strains were also checked by the perpendicular streak method of Abbott \& Shannon (1958), a qualitative test involving inhibition by bacteriocine produced during growth of a streak of the producer organism on the plate. This test was not very satisfactory, giving positive results only where the plate assay had already indicated a marked sensitivity to a pyocine. Any reaction (i.e. the result of the action of a given producer on a given indicator) giving a positive result for pyocine in both plate assay and streak test was scored positive, and not investigated further. Reactions showing positive in one test, but negative in the other, were re-tested by the technique of Gratia (1947), which utilizes bacteriocine production by clones of the producer strain growing in the depth of the agar. Only when at least two positive reactions could be obtained from the three tests was the overall reaction scored positive.

Plate assay of culture supernatants. Serial tenfold dilutions (to $10^{-5}$ ) of irradiated and control (unirradiated) cultures of each strain were prepared in tryptone broth, and standard drops of approximately $0.01 \mathrm{ml}$. were placed on indicator plates seeded with one drop of an overnight culture of the indicator strain. After $16 \mathrm{hr}$ incubation at $37^{\circ}$, the plates were examined. In some cases, complete inhibition of growth occurred even at high dilutions, due to confluent lysis by high concentrations of phage, which obscured the action of any pyocine which might be present. In such cases, the diluted samples were irradiated strongly $(10 \mathrm{~min}$. at $25 \mathrm{~cm}$.) to inactivate the phage, and again assayed for pyocine activity. It was assumed that this treatment would not inactivate any pyocine present. Three strains, 8060, 119 and 20, produced phages which were exceptionally resistant to u.v. irradiation, and, as the plaques formed by these phages were exceptionally large (3-5 $\mathrm{mm}$.), confluent lysis occurred when relatively few phage particles were present.

Growth inhibition might also be caused by low molecular weight catabolic products, or by enzymes (extracellular or intracellular) derived from the producer organism. Non-specific inhibition by low molecular weight catabolic products was excluded by assaying dialysed samples of the supernatants of the irradiated cultures. The antibacterial activity of dialysed and non-dialysed samples was the same. A purified preparation of the pyocine of strain c 10 was completely inactivated by treatment for $5 \mathrm{~min}$. in a $\mathbf{1} \mathrm{kW}$. Mullard ultrasonic disintegrator. After similar treatment of the culture supernatant fluids of each strain, the residual antibacterial 
activity was negligible. Since enzymes such as the endolysin of Escherichia coli can withstand such treatment (Waites \& Fry, 1964) it is unlikely that the 'bacteriocine' activity was due to bacteriolytic enzymes of this type.

Streaking test. The procedure of Abbott \& Shannon (1958) was followed, the producer organisms being grown on the plates for 2 days before sterilization with chloroform vapour. In addition to the inhibition of indicator growth for $1-2 \mathrm{~cm}$. over the position of the producer streak, characteristic of bacteriocine activity, a second type of reaction, in which growth of the indicator organism occurred over the producer streak but was interrupted for 1-2 mm. on either side, seemed to be associated with bacteriophage action.

Gratia two-layer technique (Gratia, 1947). Plates were seeded with the producer organism so as to give between 20 and 50 colonies per plate. The seeded layer was over-layered with another soft agar layer $(2.5 \mathrm{ml}$.), and the plates incubated 3 days at $37^{\circ}$. The indicator strain was then seeded on to the top of the agar, and examined for growth inhibition after a further $16 \mathrm{hr}$ incubation.

\section{RESULTS}

Preliminary screening of all strains by using drops of overnight culture supernatant fluids indicated the presence of many bacteriocine and phage reactions among the various strains of Pseudomonas aeruginosa (Fig. 1). None of the $\boldsymbol{P}$. fluorescens strains were bacteriocinogenic, and only one was bacteriocine sensitive; three strains were lysogenic for a phage active against $P$. aeruginosa 5083. $P$. ovalis Chester was inactive in all respects.

All the 31 strains of Pseudomonas aeruginosa systematically examined were pyocinogenic and all but 5 were also lysogenic. The pyocine of strain $24 / 1$ was more heat-labile than the others, and it was necessary to sterilize the lysate with chloroform before testing. This strain gave positive reactions only when unheated material was used in the initial screening test. All the pyocines appeared to be u.v.-inducible, different strains showing an increase in pyocine production of between 10- and 1000-fold in the irradiated culture as compared with an unirradiated control. Of the 26 lysogenic strains, 21 showed similar increases in the amount of phage present after irradiation. Strains 6749,6750 and 6751 showed less phage in the irradiated sample than in the control, titration by plaque count on a suitable indicator giving titres after irradiation of 30,68 and $60 \%$ respectively of the controls. The phages carried by these strains do not therefore appear to be u.v.-inducible. Strains $\mathbf{5 0 8 3}$ and 8203 showed only a twofold increase in phage production after irradiation. It is possible that in all these strains there was interference between bacteriocine and phage production similar to that observed by Frédéricq (1955) and by Kellenberger \& Kellenberger (1956), and in consequence the phage yield was reduced.

The systematic cross-testing revealed that the pyocines of many strains could be arranged in groups with similar or identical action spectra, and that strains within each group were generally resistant to pyocines produced by other members of the group (Fig. 2). Since no strain was sensitive to its own pyocine, this would seem to be evidence in favour of the close similarity between the pyocines of the strains in each group, even though in many cases slight differences in spectra were evident. In Fig. 2, areas of cross-resistance between members of each group have been enclosed 
in squares for clarity. Four main pyocine groups could be distinguished, into which all but 6 of the strains could be fitted.

A large group, designated group A, contains 13 strains producing pyocins which are active against almost all other strains apart from those within the group. Crossresistance in group $\mathbf{A}$ is not complete, and the pyocines show rather wide quantitative

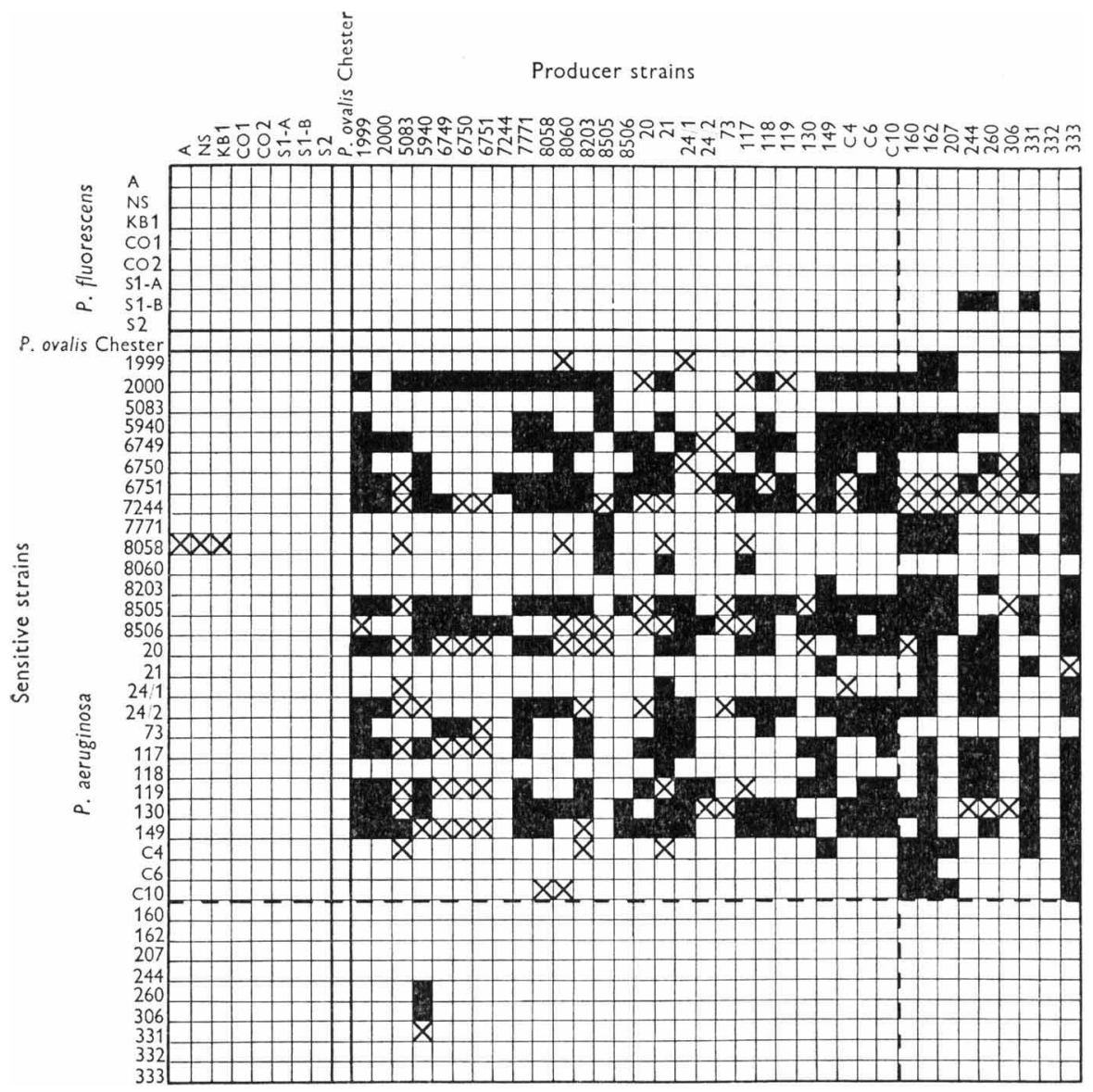

Fig. 1. Bacteriocin and phage interactions among Pseudomonas species. Drops $(0.01 \mathrm{ml}$.) of overnight broth culture supernatant fluids of each strain were tested for their ability to inhibit the growth of every other strain on nutrient agar plates. The inhibition zones were touched with a platinum wire which was washed in $1 \mathrm{ml}$. broth, and re-tested on a second indicator plate. A solid square denotes inhibition on the first plate only, assumed to be due to bacteriocine action; a cross denotes inhibition on both indicator plates, assumed to be due to phage or to phage plus bacteriocine. Heavy lines divide strains of different species; dotted lines separate the 27 strains of Pseudomonas aeruginosa used in the detailed classification of pyocines from those not included.

differences in their spectra, with a graded decrease in activity towards group B strains proceeding from left to right in the diagram. However, it seems difficult to justify subdivision of the group on the basis of action spectra alone. Group B contains 5 strains, with only slightly differing spectra, whose cross-resistance is complete. Group C includes 3 strains with identical spectra and strain 130, which, 
although its spectrum differs from the others at four points, has been included on the grounds of its resistance to other members of the group. The pyocines of group $\mathrm{C}$ are characterized by their action against strain 5083 , and by the large number of strains which are resistant or only slightly sensitive to them. Group D includes 3 strains, 2 of which show only very weak reactions.

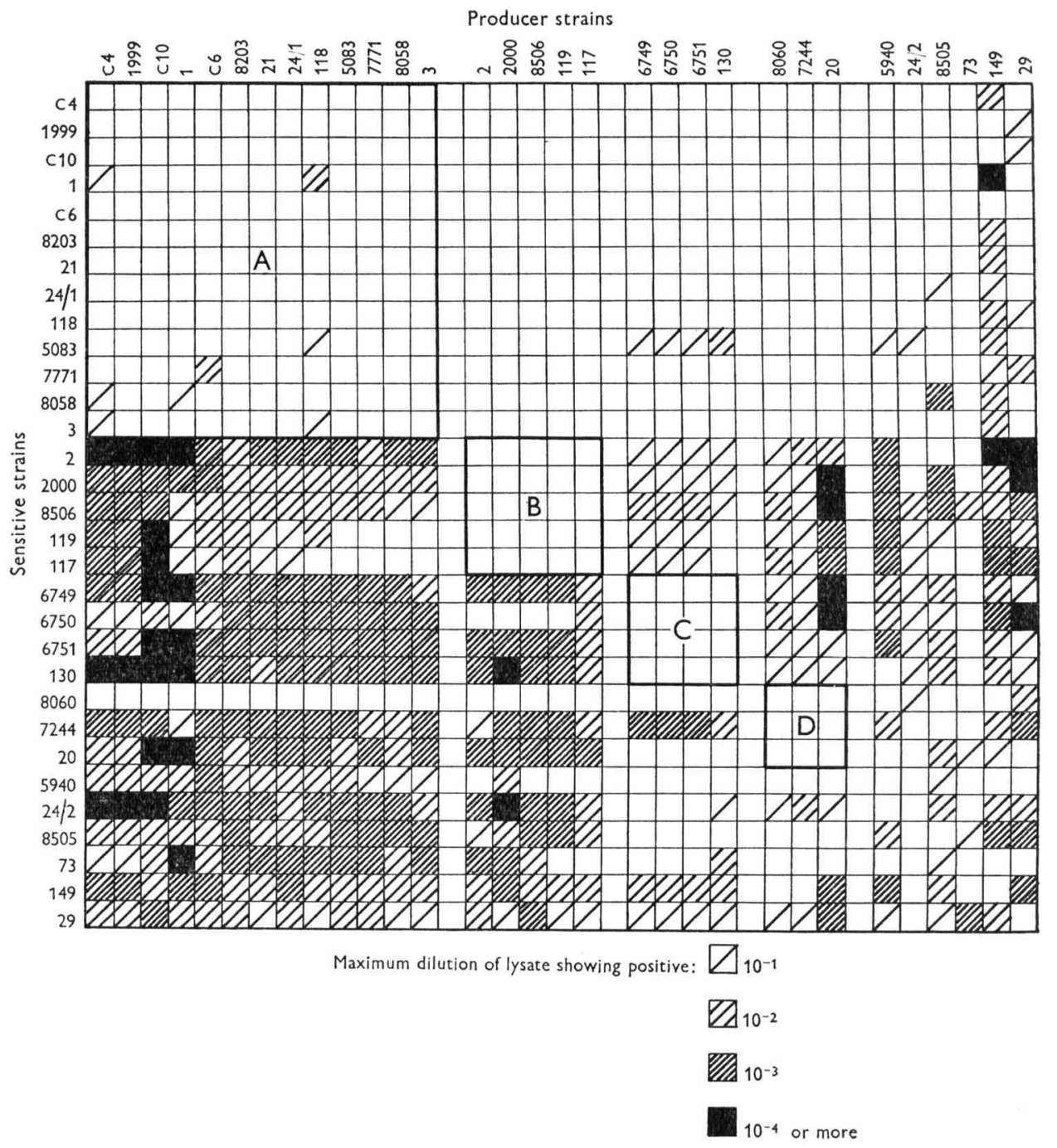

Fig. 2. Action spectra of pyocines from Pseudomonas aeruginosa. Each strain was tested for its sensitivity to the pyocine produced by every other strain, by plating serial dilutions of the supernatant fluids of irradiated cultures, and examining for the greatest dilution giving a discernible inhibition zone. Capital letters designate the pyocin type of each group of producer strains.

Of the remaining 6 strains, it is possible that some may show multiple pyocinogeny, since their pyocine spectra overlap with one or more of those within the four main groups. For example, strain $\mathbf{5 9 4 0}$ gives a spectrum which overlaps with those of 
the pyocines of groups $\mathrm{C}$ and $\mathrm{D}$, and moreover is resistant to all but one pyocine in these groups. Strain 149 shows a very wide spectrum, correlating fairly closely with both 8505 and 24/2. However, since the pyocine(s) produced by strain 149 is (are) active against 3 strains which are otherwise pyocine-resistant, and is active against most group A strains, the wide spectrum may indicate only one rather rare pyocine.

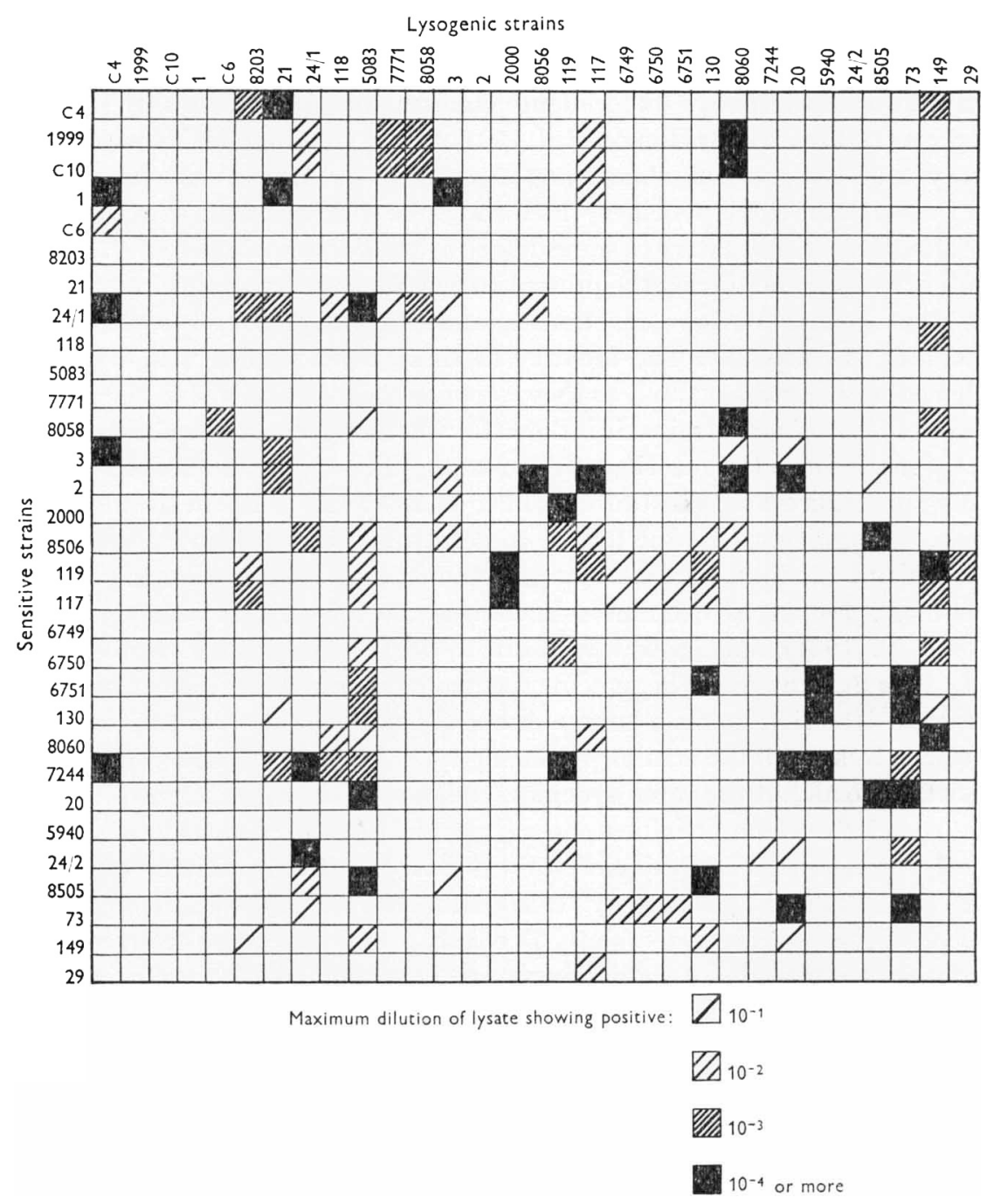

Fig. 3. Action spectra of phages from Pseudomonas aeruginosa. Each strain was tested for its sensitivity to the phage produced by every other strain, by plating serial dilutions of the supernatant fluids of irradiated cultures, and examining for the greatest dilution giving plaques in the area of the assay drop.

The spectra of phages from the 31 strains (Fig. 3) do not show the same groupings as the pyocines. The phages have generally very much narrower spectra than the pyocines, and five strains $(8203,21,5083,7771,5940)$ show complete phage resistance. The considerable overlapping of the phage spectra of different strains indicates that 
many may be lysogenic for more than one phage. While there is no general correlation between the phage produced and the pyocine type of any given strain, it is notable that those strains which produce phage with identical spectra also produce pyocines of the same type. Thus strains 7771 and 8058 produce both phage and pyocine with identical spectra, and so also do strains 6749,6750 and 6751 .

\section{DISCUSSION}

The results of the above experiments confirm the observations of Hamon and co-workers (Hamon, 1956; Hamon et al. 1961) on the very high incidence of bacteriocinogeny and lysogeny in Pseudomonas aeruginosa. However, whereas Hamon found that at least three pyocines which showed a wide spectrum of activity against $\boldsymbol{P}$. aeruginosa were also active to some degree against certain strains of $\boldsymbol{P}$. fluorescens, no evidence was found during the present survey for activity against another species of the same genus. Positive reactions against $\boldsymbol{P}$. fluorescens s $1-\mathrm{B}$ were given by strains 207, 244 and 331. The identity of these three strains was, however, not established with certainty, and, as they were generally insensitive to the pyocines of authentic $P$. aeruginosa strains, it is doubtful whether they can be classed as typical $\boldsymbol{P}$. aeruginosa. Since the reactions shown among $\boldsymbol{P}$. aeruginosa strains in the initial screening procedure were substantially in agreement with those in the more detailed analysis, it is unlikely that the failure to detect activity against $\boldsymbol{P}$. fluorescens was due to faulty technique. The absence of demonstrable bacteriocinogeny among the strains of $\boldsymbol{P}$. fluorescens examined, in contrast to the $44 \%$ incidence reported by Hamon et al. (1961), may, however, be due to the relatively small number of strains tested. It is evident from the pyocine spectrum diagram (Fig. 2) that bacteriocines may escape detection unless a large number of possible sensitive strains are used as indicators. Nearly all the strains producing type A pyocines (13 out of 31 studied) are resistant to all but the rarer pyocines, and none of the other strains is sensitive to all the pyocines. General indicators, e.g. strain P10s of Hamon et al. (1961), are evidently rare, so that bacteriocine surveys based on the sensitivity of only a few strains, such as those by Holloway (1960), Hamon et al. (1961) and Hamon \& Péron $(1961,1963)$ may well be incomplete. The tests used in the present investigation of $\boldsymbol{P}$. aeruginosa strains have shown every strain examined to be pyocinogenic, including Holloway's strain 2, previously reported as non-pyocinogenic (Dr B. W. Holloway, personal communication).

The cross-resistance of individual bacterial mutants each selected for resistance to a particular bacteriocine is a more satisfactory basis for bacteriocine typing than the sensitivity of any naturally occurring strain or strains (Frédéricq, 1953). However, mutation to pyocine resistance seems to be rare, unlike the situation among colicin-sensitive strains, where mutation to colicin resistance is a relatively common occurrence (Frédéricq, 1948), and pyocine-resistant colonies have not so far been observed in this laboratory. Use has therefore been made of the fact that, while all strains are pyocinogenic, none is sensitive to its own pyocine. Pyocine types have been classified according to the resistance not of selected mutants, but of wild-type strains producing a supposedly homologous pyocine. When classified on this basis, however, the pyocines within each group show small heterogeneities in their spectra, and, although this amounts in some cases only to differences in the degree of sensi- 
tivity of certain strains, the possibility of subdivision of the main groups arises. Similar small differences in the spectra of many of the colicines investigated by Frédéricq (1948) were later found to be insignificant, and the original 17 types were reduced to 12 by regrouping on the basis of the sensitivities of colicine-resistant mutants. Unequivocal evidence of the identity of the pyocines in each of the major groups (A, B, C, D) described above must await the selection of resistant mutants, the use of antigenic methods, or studies with the purified compounds. The pyocine of Pseudomonas aeruginosa $\mathrm{c} 10$ is being purified, and will be reported on in a separate publication. A serological study of the somatic antigens of strains of each pyocine group has shown that the strains of any one group are related antigenically, and differ from those of the other three groups.

I am indebted to Dr B. A. Fry for many helpful suggestions during this work, which was supported by a grant from the Agricultural Research Council.

\section{REFERENCES}

Aвbott, J. D. \& Shannon, R. (1958). A method for typing Shigella sonnei using colicin production as a marker. J. clin. Path. 11, 71.

Ben-Gurion, R. \& Hertman, I. (1958). Pesticins. J. gen. Microbiol. 19, 289.

Brubaker, R. R. \& Surgalla, M. J. (1961). Pesticins: pesticin-bacterium interrelationships and environmental factors influencing activity. J. Bact. 82, 940.

FrédéricQ, P. (1948). Antibiotiques réciproques chez les Enterobacteriaceae. Revue belge Path. Méd. exp. 19 (Suppl. 4), 1.

FrédÉricQ, P. (1953). Recherches sur les charactères et la distribution des souches productrices de diverses colicines dans les celles normales et pathologiques. Bull. Acad. r. Méd. Belg. 18, 126.

FréDÉricQ, P. (1955). Induction de la production de colicine et de bactériophages par induction u.-v. de souches colicinogènes et lysogènes de Escherichia coli. C. r. Séanc. Soc. Biol. 149, 2028.

Gratia, A. (1925). Sur un remarquable exemple d'antagonisme entre deux souches de Colibacille. C. r. Séanc. Soc. Biol. 93, 1040.

Gratia, A. (1947). Technique de la 'double-couche'. Bull. Soc. Chim. biol. 29, 352.

Hamon, Y. (1956). Contribution à l'étude des pyocines. Annls Inst. Pasteur, Paris, 91, 82.

Hamon, Y. \& Péron, Y. (1961). Étude de la propriété bactériocinogène dans le genre Serratia. Annls Inst. Pasteur, Paris, 100, 818.

HAMON, Y. \& PÉron, Y. (1963). Étude de pouvoir bactériocinogène dans le genre Listeria. II. Individualité et classification des bactériocines en cause. Annls Inst. Pasteur, Paris, 104,55 .

Hamon, Y., VÉron, M. \& PÉron, Y. (1961). Contribution à l'étude des propriétés lysogènes et bactériocinogènes dans le genre Pseudomonas. Annls Inst. Pasteur, Paris, 101, 738.

Holloway, B. W. (1960). Grouping Pseudomonas aeruginosa by lysogenicity and pyocinogenicity. J. Path. Bact. 80, 448.

Ivánovics, G. \& AtföLdI, L. (1954). A new antibacterial principle-megacine. Nature, Lond. 174, 465.

$\mathrm{J}_{\mathrm{ACOB}}$, F. (1954). Biosynthèse induite et mode d'action d'une pyocine, antibiotique de Pseudomonas pyocyanea. Annls Inst. Pasteur, Paris, 86, 149.

Kellenberger, G. \& Kellenberger, E. (1956). Études de souches colicinogènes au microscope électronique. Schweiz. Z. allg. Path. 19, 582.

NAGy, E., Alföldi, L. \& Ivánovics, G. (1959). Megacins. Acta microbiol. hung. 6, 327.

Wartes, W. M. \& FrY, B. A. (1964). Effect of infection with phage lambda on the synthesis of protein, RNA and DNA in Escherichia coli. J. gen. Microbiol. 34, 413. 